\title{
Effect of Gibberllic Acid, Thiourea and Potassium Nitrate on Seed Germination and Embryo Growth of Cupressus sempervirens var. pyramidalis and $C$. sempervirens var. horizontalis
}

\author{
Nadia A. El-Malki ${ }^{*}$ and Ali. El-Bakkosh ${ }^{1}$ \\ ${ }^{1}$ Botany Department, Faculty of Science, Benghazi University, Benghazi, Libya. \\ Received: 11 January 2016 /Accepted: 2 May 2016 \\ *Corresponding author: Nadia29elmalki@gmail.com
}

\begin{abstract}
Cupressus sempervirens, the climacteric forest vegetation of El-Jable El-Akhdar (Libya), has two varieties: pyramidalis and horizontalis; both exhibit pronounced seed dormancy which participates in extinction of their natural vegetation. The present study investigates the effect of seed pretreatment with GA3 and thiourea at concentrations of $0,50,100,200$ and $400 \mathrm{mg} / \mathrm{L}$, and with KNO3 at concentrations of 0 and $0.2 \%$ on seed germination and embryo growth of the two varieties of $C$. sempervirens. Seed germinability was higher in horizontalis variety than in pyramidalis, but rate of germination as well as embryo extension was comparable in the two varieties. Both seed germinability and embryo growth were higher in GA3 than in thiourea. Rate of germination - in terms of mean germination time - was non-significantly affected by treatments (variety, type of chemical and chemical concentration). By contrast, germinability and embryo extension increased with the increase in concentrations of GA3 and thiourea up to an optimum of 50-100 mg/L, beyond which they progressively declined. The exact optimum concentration, the magnitude of promotion at that optimum and the magnitude of retardation beyond the optimum varied according to variety and the chemical used. KNO3 at a concentration of $0.2 \%$ had limited effect on seed germination of the two varieties as well as embryo extension of horizontalis variety compared with that of GA3 and thiourea but increased embryo extension of pyramidalis variety to more than twice the control.
\end{abstract}

Keywords: Seed dormancy; Cupressus; GA3, thiourea, potassium nitrate.

\section{Introduction}

Seeds of many wild plants are dormant when first shed and will not sprout even when exposed to adequate moisture and oxygen supplies and appropriate temperature (Salisbury and Ross, 1978). This phenomenon is due to several causes including the hard seed coat which restricts embryo expansion, impermeability of seed coat to water and gases and the immature embryo. Many practices have been used to break seed dormancy among which is dipping seeds in sulphuric acid of different concentrations to soften the hared seed coat (Hadad, 1995) and treatment with the plant hormone gibberellic acid $\left(\mathrm{GA}_{3}\right)$ (Abdalla \& Mckelvie, 1980), thiourea (Ibrahim \& Haikel, 1991) and potassium nitrate (ISTA, 1993).

In Libya, El-Jable El-Akhdar has unique plant cover of many wild tree species in the form of frosts which in turn provide the appropriated micro-environment to numerous understory herbs and shrubs. Cupressus species are among the most important frost trees native to this region where they cover a large area of the land (Sherif and El-Taife, 1986). The natural vegetation of this 
area is suffering from undue practices including overgrazing, trampling, fires, over cutting and uprooting of plants (El-Barasi and Buhwarish, 2005). Seeds of Cupressus sempervirens L. var horizontalis and var. pyramidalis exhibit pronounced dormancy which may lead to limitation and deterioration of the natural vegetation of these varieties (El-Bakkosh, 2001). The present study investigates the efficiency of different treatments in breaking seed dormancy and hastening seedling growth of two varieties of Cupressus grown naturally in El-Jable El-Akhdar (Libya).

\section{Materials and methods}

The seeds of two Cupressus varieties were collected randomly from different sectors of ElJable El-Akhdar (Libya). The seeds were dipped in tap water to eliminate shriveled seeds. A random sample of 100 seeds of each variety was subjected to the teterazolium seed viability test of ISTA (1993). Seeds were sterilized with $10 \%$ sodium hypochlorite for $5 \mathrm{~min}$ followed by washing with distilled water. The seeds were then dipped in concentrated $\mathrm{H} 2 \mathrm{SO} 4$ for $10 \mathrm{~min}$, washed thoroughly and blotted dry. The seeds were then soaked in different concentrations $(0,50,100,200$ and $400 \mathrm{mg} / \mathrm{L}$ ) of GA3 and thiourea and in $0.2 \%$ KNO3 for $24 \mathrm{~h}$. After soaking, seeds were germinated in Petri dishes lined with filter papers moistened with distilled water (20 seed / dish) in a growth chamber at $30^{\circ} \mathrm{C} / 12 \mathrm{~h}$ light and $20^{\circ} \mathrm{C} / 12$ darkness.

Number of germinated seeds was recorded frequently for a period of 5 weeks. Seeds were considered germinated when the radicle emerged to a length of $2 \mathrm{~mm}$. The final germination percentage and the mean germination time (MGT) were calculated according to Rawal et al. (1998). The lengths of radicles and plumules were recorded.

The experiment was factorial with three main factors and four replications in a completely randomized design (CRD). The main factors were plant variety, type of pre-treatment chemical and chemical concentration. Final germination percentage was arcsine transformed before doing ANOVA to ensure homogeneity of variance. ANOVA was performed using SPSS program version 22. Mean separation was done according to the Tukey's test.

\section{Results}

Table 1 shows the effects of main factors (variety, type of chemical and chemical concentration) on germination parameters and embryo growth of Cupressus sempervirens. The germination parameters estimated were germinability in terms of the cumulative final germination percentage and rate of germination in terms of mean germination time (MGT), which is an inverse measure of rate of germination. Embryo growth was estimated in terms of lengths of radicle and plumule. Treatments substantially (very highly significantly, $\mathrm{p}<0.001)$ affected magnitude of germination but had relatively limited effect on rate of germination; where MGT was nonsignificantly affected by variety and type of chemical but highly significantly affected by concentration only. Embryo growth was comparable in the two varieties but was very highly significantly affected by type of chemical and chemical concentration.

Table 1 Three-way ANOVA of the effects of main factors (variety, type of chemical and chemical concentration) on germination parameters and embryo growth of Cupressus sempervirens.

\begin{tabular}{|c|c|c|c|c|c|}
\hline $\begin{array}{l}\text { Source } \\
\text { variation }\end{array}$ & $\begin{array}{l}d \\
f\end{array}$ & $\mathrm{~F}$ & $\mathrm{P}$ & $\mathrm{F}$ & $\mathrm{P}$ \\
\hline & & $\begin{array}{l}\text { Final } \\
\text { (deg.) }\end{array}$ & germination & $\begin{array}{l}\text { Plumule } \\
\text { length }\end{array}$ & \\
\hline Variety & 1 & 27.10 & 0.000 & $\overline{0.007}$ & 0.934 \\
\hline Chemical & 1 & 11.94 & 0.001 & 142.6 & 0.000 \\
\hline \multirow[t]{2}{*}{ Concentration } & 4 & 17.38 & 0.000 & 48.46 & 0.000 \\
\hline & & \multicolumn{2}{|c|}{$\underline{\text { Mean germination time }}$} & $\frac{\text { Radicle }}{\text { length }}$ & \\
\hline Variety & 1 & 0.000 & 1.000 & $\overline{0.933}$ & 0.338 \\
\hline Chemical & 1 & 0.422 & 0.518 & 152.5 & 0.000 \\
\hline Concentration & 4 & 5.689 & 0.001 & 47.29 & 0.000 \\
\hline
\end{tabular}

Seed germinability was in general higher in horizontalis variety of Cupressus than in pyramidalis variety; and in both varieties it was higher in $\mathrm{GA}_{3}$ than in thiourea (Tables 2 and 3). Germinability of the two Cupressus varieties increased with the increase in pretreatment concentration of $\mathrm{GA}_{3}$ and thiourea up to a certain level, beyond which germinability progressively decreased with further increase in concentration up to $400 \mathrm{mg} / \mathrm{L}$. The optimum concentration, the magnitude of promotion of germination at that optimum and the magnitude of retardation beyond the optimum concentration varied according to variety and the chemical used. Germinability increased by $56 \%$ and $72 \%$ as $\mathrm{GA}_{3}$ concentration increased from 0 to $100 \mathrm{mg} / \mathrm{L}$ and from 0 to 50 $\mathrm{mg} / \mathrm{L}$ in horizontalis and pyramidalis varieties respectively; and this was followed by $48 \%$ and $73 \%$ reductions respectively upon further increase 
in $\mathrm{GA}_{3}$ concentration beyond these optima up to $400 \mathrm{mg} / \mathrm{L}$. By contrast, germinability increased by $26 \%$ and $4 \%$ with the increase in thiourea concentration from 0 to $50 \mathrm{mg} / \mathrm{L}$ and from 0 to 100 $\mathrm{mg} / \mathrm{L}$ in horizontalis and pyramidalis varieties respectively; with subsequent reductions of $36 \%$ and $66 \%$ respectively upon further increase in thiourea concentration beyond these optima up to $400 \mathrm{mg} / \mathrm{L}$. Pretreatment of seeds with $0.2 \% \mathrm{KNO}_{3}$ $(2000 \mathrm{mg} / \mathrm{L})$ increased gerninability by $21 \%$ and $32 \%$ above the control in horizontalis and pyramidalis varieties respectively. In contrast to their marked effect on germinability, treatments had non-significant effect on mean germination time of the two varieties and the MGT averaged around 7.2 days irrespective of the variety and type and concentration of the chemical.

Table 2. Effect of gibberellic acid $\left(\mathrm{GA}_{3}\right)$, thiourea and potassium nitrate on mean germination time (MGT) and seed germinability (final germination \%) of Cupressus._sempervirens var horizontalis. Each value is the mean of 4 replicates $\pm \mathrm{SE}$

\begin{tabular}{ccc}
\hline Treatment & $\begin{array}{c}\text { Mean } \\
\text { Germination } \\
\text { Time (day) }\end{array}$ & $\begin{array}{c}\text { Final } \\
\text { germination \% }\end{array}$ \\
\hline Control & $7.30 \pm 0.48^{\mathrm{a}}$ & $25.67 \pm 2.45^{\mathrm{a}}$ \\
\hline$\underline{\mathrm{GA}} \frac{(\mathrm{mg} / \mathrm{L})}{50}$ & $7.30 \pm 0.47^{\mathrm{a}}$ & $35.00 \pm 3.84^{\mathrm{b}}$ \\
100 & $7.30 \pm 0.48^{\mathrm{a}}$ & $40.17 \pm 4.49^{\mathrm{bc}}$ \\
200 & $7.30 \pm 0.50^{\mathrm{a}}$ & $30.33 \pm 3.23^{\mathrm{c}}$ \\
400 & $7.30 \pm 0.55^{\mathrm{a}}$ & $21.00 \pm 2.52^{\mathrm{e}}$ \\
\hline Thiourea $(\mathrm{mg} / \mathrm{L})$ & & \\
\hline 50 & $7.10 \pm 0.49^{\mathrm{a}}$ & $32.50 \pm 3.02^{\mathrm{a}}$ \\
100 & $7.10 \pm 0.49^{\mathrm{a}}$ & $31.01 \pm 3.16^{\mathrm{ab}}$ \\
200 & $7.10 \pm 0.47^{\mathrm{a}}$ & $30.17 \pm 2.84^{\mathrm{abc}}$ \\
400 & $7.10 \pm 0.55^{\mathrm{a}}$ & $20.83 \pm 2.50^{\mathrm{d}}$ \\
\hline $0.2 \% \mathrm{KNO}_{3}$ & $7.30 \pm 0.51^{\mathrm{a}}$ & $31.00 \pm 3.40$ \\
\hline
\end{tabular}

Table 3. Effect of gibberellic acid $\left(\mathrm{GA}_{3}\right)$, thiourea and potassium nitrate on mean germination time (MGT) and seed germinability (final germination \%) of Cupressus._sempervirens var pyramidalis. Each value is the mean of 4 replicates $\pm \mathrm{SE}$.

\begin{tabular}{ccc}
\hline Treatment & $\begin{array}{c}\text { Mean } \\
\text { Germination } \\
\text { Time (day) }\end{array}$ & $\begin{array}{c}\text { Final } \\
\text { germination } \%\end{array}$ \\
\hline Control & $7.30 \pm 0.63^{\mathrm{a}}$ & $22.83 \pm 2.80^{\mathrm{bce}}$ \\
\hline$\frac{\mathrm{GA}_{3}(\mathrm{mg} / \mathrm{L})}{50}$ & $7.30 \pm 0.47^{\mathrm{a}}$ & $39.33 \pm 2.27^{\mathrm{a}}$ \\
100 & $7.30 \pm 0.48^{\mathrm{a}}$ & $33.17 \pm 3.89^{\mathrm{ab}}$ \\
200 & $7.30 \pm 0.49^{\mathrm{a}}$ & $22.67 \pm 2.78^{\mathrm{c}}$ \\
400 & $7.30 \pm 0.65^{\mathrm{a}}$ & $10.83 \pm 1.66^{\mathrm{d}}$ \\
\hline$\frac{}{\text { Thiourea }}$ & & \\
$\frac{(\mathrm{mg} / \mathrm{L})}{50}$ & $7.10 \pm 0.55^{\mathrm{a}}$ & $23.33 \pm 2.89^{\mathrm{ab}}$ \\
100 & $7.10 \pm 0.51^{\mathrm{a}}$ & $23.83 \pm 3.0^{\mathrm{a}}$ \\
200 & $7.10 \pm 0.56^{\mathrm{a}}$ & $17.83 \pm 2.3^{\mathrm{abc}}$ \\
400 & $7.10 \pm 0.90^{\mathrm{a}}$ & $8.17 \pm 1.40^{\mathrm{d}}$ \\
\hline $0.2 \% \mathrm{KNO}_{3}$ & $7.10 \pm 0.54^{\mathrm{a}}$ & $30.17 \pm 3.32$ \\
\hline
\end{tabular}

Embryo extension was comparable in the two Cupressus varieties but was improved by application of chemicals where the effect of $\mathrm{GA}_{3}$ pretreatment was greater than that of thiourea (Tables 4 and 5). Increasing $\mathrm{GA}_{3}$ concentration from 0 to $100 \mathrm{mg} / \mathrm{L}$ increased lengths of plumule and radicle of horizontalis variety by an average of 4 fold, followed by a sharp reduction of $98 \%$ upon further increase in $\mathrm{GA}_{3}$ concentration from 100 to $400 \mathrm{mg} / \mathrm{L}$. In pyramidalis variety increasing $\mathrm{GA}_{3}$ concentration from 0 to $50 \mathrm{mg} / \mathrm{L}$ increased lengths of plumule and radicle by about 3 fold, followed by a sharp reduction of $90 \%$ upon further increase in $\mathrm{GA}_{3}$ concentration from 50 to $400 \mathrm{mg} / \mathrm{L}$. Increasing thiourea concentration from 0 to $100 \mathrm{mg} / \mathrm{L}$ increased lengths of plumule and radicle of horizontalis variety by an average of $58 \%$, but further increase in thiourea concentration from 100 to $400 \mathrm{mg} / \mathrm{L}$ reduced lengths of plumule and radicle by $82 \%$ and $68 \%$ respectively. In pyramidalis variety lengths of plumule and radicle were progressively reduced by $89 \%$ and $80 \%$ respectively with the increase in thiourea concentration from 0 to $400 \mathrm{mg} / \mathrm{L}$. Pretreatment with $0.2 \% \quad \mathrm{KNO}_{3}$ did not significantly affect embryo extension of horizontalis variety but increase lengths of plumule and radicle of pyramidalis variety to more than twice the control value.

Table 4. Effect of gibberellic acid, thiourea and potassium nitrate on plumule and radicle lengths of $C$. sempervirens var. horizontalis. Each value is the mean of 4 replicates $\pm \mathrm{SE}$.

\begin{tabular}{ccc}
\hline Treatment & $\begin{array}{c}\text { Plumule length } \\
(\mathbf{m m})\end{array}$ & $\begin{array}{c}\text { Radicle length } \\
(\mathbf{m m})\end{array}$ \\
\hline Control & $3.41 \pm 0.57^{\mathrm{ce}}$ & $4.29 \pm 0.66^{\mathrm{cd}}$ \\
\hline$\frac{\mathrm{GA}}{3}(\mathrm{mg} / \mathrm{L})$ & & \\
50 & $10.72 \pm 1.14^{\mathrm{a}}$ & $11.87 \pm 1.18^{\mathrm{b}}$ \\
100 & $17.70 \pm 1.90^{\mathrm{b}}$ & $23.01 \pm 2.40^{\mathrm{a}}$ \\
200 & $5.72 \pm 0.82^{\mathrm{c}}$ & $7.58 \pm 0.98^{\mathrm{bc}}$ \\
400 & $1.71 \pm 0.36^{\mathrm{de}}$ & $2.86 \pm 0.47^{\mathrm{d}}$ \\
\hline Thiourea $(\mathrm{mg} / \mathrm{L})$ & & \\
50 & $4.67 \pm 0.73^{\mathrm{ce}}$ & $5.56 \pm 0.76^{\mathrm{cd}}$ \\
100 & $5.40 \pm 0.75^{\mathrm{cd}}$ & $6.85 \pm 0.88^{\mathrm{cd}}$ \\
200 & $2.15 \pm 0.34^{\mathrm{ce}}$ & $3.60 \pm 0.44^{\mathrm{cd}}$ \\
400 & $1.02 \pm 0.23^{\mathrm{e}}$ & $2.19 \pm 0.36^{\mathrm{d}}$ \\
\hline $0.2 \% \mathrm{KNO}_{3}$ & $3.06 \pm 0.52^{\mathrm{cde}}$ & $4.90 \pm 0.69^{\mathrm{cd}}$ \\
\hline
\end{tabular}

Table 5. Effect of gibberellic acid, thiourea and potassium nitrate on plumule and raicle lengths of $C$. sempervirens var pyramidalis. Each value is the mean of 4 replicates $\pm \mathrm{SE}$.

\begin{tabular}{lll}
\hline Treatment & $\begin{array}{l}\text { Plumule length } \\
(\mathrm{mm})\end{array}$ & $\begin{array}{l}\text { Radicle length } \\
(\mathrm{mm})\end{array}$ \\
\hline Control & $4.99 \pm 0.71^{\mathrm{c}}$ & $5.72 \pm 0.80^{\mathrm{c}}$ \\
\hline
\end{tabular}




\begin{tabular}{lll}
\hline$\frac{\mathrm{GA}}{3}(\mathrm{mg} / \mathrm{L})$ & & \\
50 & $18.18 \pm 2.10^{\mathrm{a}}$ & $24.10 \pm 2.87^{\mathrm{a}}$ \\
100 & $12.03 \pm 1.49^{\mathrm{b}}$ & $13.11 \pm 1.57^{\mathrm{b}}$ \\
200 & $4.44 \pm 0.68^{\mathrm{c}}$ & $5.39 \pm 0.76^{\mathrm{c}}$ \\
400 & $1.85 \pm 0.36^{\mathrm{c}}$ & $2.23 \pm 0.39^{\mathrm{c}}$ \\
\hline Thiourea (mg/L) & & \\
50 & $3.87 \pm 1.17^{\mathrm{c}}$ & $3.45 \pm 0.46^{\mathrm{c}}$ \\
100 & $2.75 \pm 0.42^{\mathrm{c}}$ & $3.76 \pm 0.49^{\mathrm{c}}$ \\
200 & $1.91 \pm 0.34^{\mathrm{c}}$ & $2.71 \pm 0.43^{\mathrm{c}}$ \\
400 & $0.55 \pm 0.17^{\mathrm{c}}$ & $1.15 \pm 0.25^{\mathrm{c}}$ \\
\hline $0.2 \% \mathrm{KNO}_{3}$ & $11.42 \pm 1.57^{\mathrm{b}}$ & $15.42 \pm 2.17^{\mathrm{b}}$ \\
\hline
\end{tabular}

\section{Discussion}

The low seed germinability of the two Cupressus sempervirens varieties (only 24\%) for native seeds can be primarily due to physiological seed dormancy and partially to mechanical restriction of the hard seed coat. Seed dormancy of the two varieties of Cupressus sempervirens which grow well in El-Jable El-Akhdar (Libya). Because of the importance of these trees that subjected to extinction in its natural habitat, like many other trees grown in the green mountain. The positive effect of $\mathrm{GA}_{3}$ is mainly due to its role in stimulating the conversion of complex reserves in the seeds to sucrose, mobile amino acids and amides as well as to limiting the inhibitory effect of ABA (Devlin, 1975; Salisbury and Ross, 1987). It overcomes seed dormancy in many plants and can act as a substitute for low temperature, long day or red light (Abu-Zeid, 1990). Nevertheless, the effect of GA3 and thiourea seems to be dosedependent. The present work revealed marked promotion of seed germinability and embryo extension by low levels of the two chemicals (50$100 \mathrm{mglL}$ ) with sharp inhibitory effect at higher levels. The effect of GA3 was more pronounced than that of thiourea. These results are in close agreement with those of Nasroun and Al-Mana (1992), Laura et al. (1998) and Rawal et al. (1998). Such a dose-dependent effect of the two compounds has been reported by Waali (1990) where they act as growth stimulators at a certain level beyond which their retarding effect becomes evident. The present results suggest that seed germinability is affected by genotype where it was in general higher in horizontalis variety of Cupressus than in pyramidalis variety and that the effect of treatments on embryo extension was by far greater than on mere emergence of the embryo (seed germination), with a limited effect on rate of germination estimated as MGT.

\section{References}

Abdalla, S.T. and Mckelvie, A.D. (1980). The interaction of chilling and gibberellic acid on the germination of seeds of ornamental plants. Seed Science and Technology, 8: 139-144.

Abu-Zeid, E.N. (1990). Plant Hormones and Their Horticultural Applications. Madboly library, Cairo, Eygpt.

Devlin, R.M. (1975). Plant Physiology. van Nostrand Company, London.

El-Bakkosh, A.M. (2001). The effect of mechanical and chemical treatments on seed germination and seedling growth of some forest trees. M. Sc. Thesis. Benghazi. Garyounis University.

El-Barasi, Y., M., \& Buhwarish, B. (2005). The effect of human activities on the soil seed bank of semidesert zone in south El-Jabel El-Akhdar in northern Cyrenaica (Libya). GSF Book Symposium Series No. 1, 57-67.

El-Hadad, A.E. (1995). Fundamentals of Seed Science and Technology. Omar Al-Mukhtar University.

Ibrahim, M.A. and Haikel. (1991). Nurseries of Horticultural Crops. Alex. University. Egypt.

International Seed Testing Association. (1993). International rules for seed testing 1993. Seed Science and Technology 21, 160-186

Laura, V.A., Alvarenga, A.A., Arrigoni, M.F. (1998). Effects of growth regulators, temperature, light, storage and other factors on the Muntingia calabura L. seed germination. Seed Scince and Technology 22: 573-579.

Nasroun, T.H. and Al-Mana, F. (1992). The effect of pre-treatment of seeds of some arid zone tree species on their germination responses. Journal of King Saud University (4): 79-93.

Nyandiga, C.O. and Mcpherson, G.R. (1992). Germination of two warm-temperature Oaks (Quercus emproyi and Quercus Arizonia). Candian Journal of Forest Research 22: 1395-1401.

Rawal, R.S., Samant, S.S., Dhar, U. (1998). Treatments to improve germination of four multipurpose trees of central sub Himalaya. Seed Science and Technology 26: 347-354.

Salisburry, F.B. and Ross C.W. (1978). Plant Physiology. Wadsworth Publishing Company Inc., Belmont, California.

Sherif, A.S. and El-Taife, A. (1986). Flora of Libya: Gymnosperms. Al-Faateh University.

Waali, S.B. (1990). Seed Dormancy and Germination. Salah El-Deen University. 


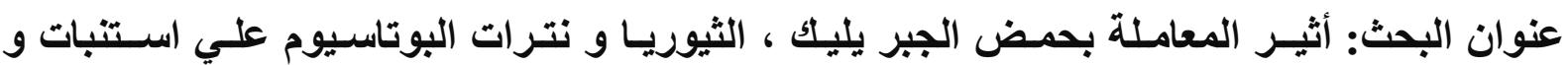

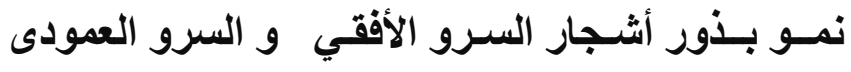

$$
\begin{aligned}
& \text { ناديـة عبد السيد المالكي و علي البكوش }
\end{aligned}
$$

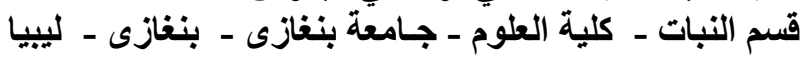

تمثل أشـجار السـرو Cupressus sempervirens بسلالتيه السرو الأفقي والسـرو العمـودي ذروة الغطاء

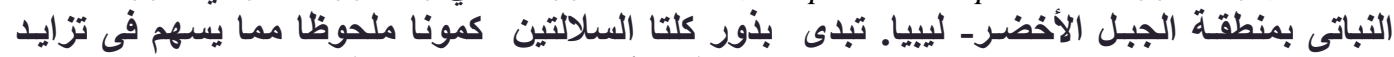

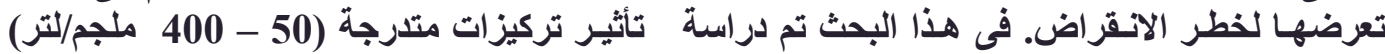

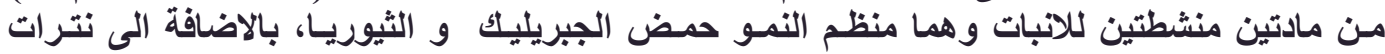

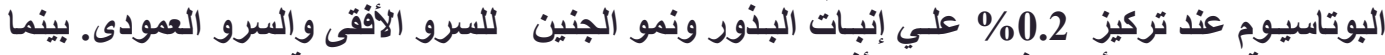

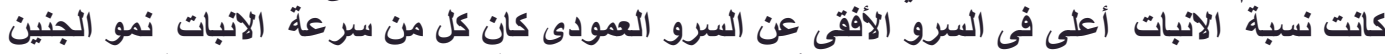

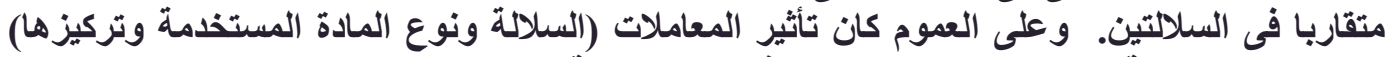

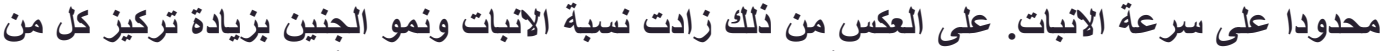

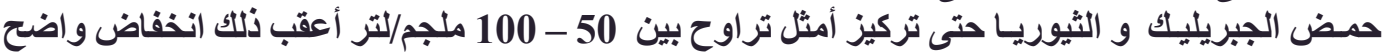

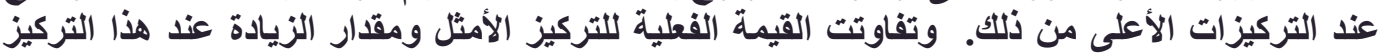

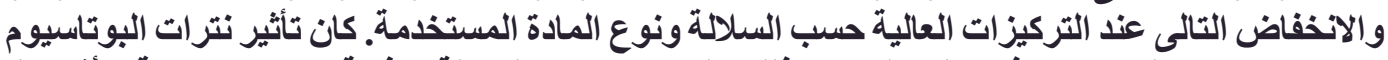

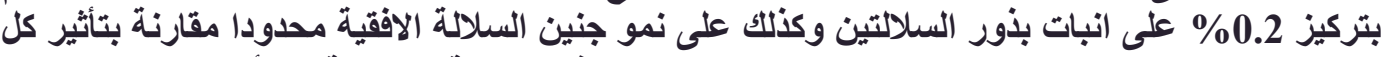

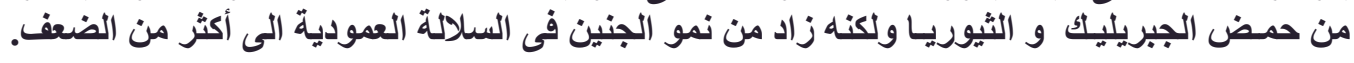

